\title{
Solar Discourse. Ancient Egyptian Ways of Worldreading
}

\author{
Von Jan Assmann (Heidelberg)
}

The consciousness of being locked within the temporal sequentiality and "mediacy" of language and the yearning for a simultaneous, an "unmediated vision" seems to be as old as western philosophy. Platonic, neoplatonic and paulinic motifs meet in Augustin's idea of an angelic way of world- or godreading where he speaks of angels "who always behold your face and read there without the temporal order of syllables" et ibi legunt sine syllabis temporum). ${ }^{1}$ But what Augustin imagined as the angelic way of world- or rather God-reading and what Paul believed to be the promise for the dead, Plotinus described as the Egyptian method of transmitting knowledge. "The Egyptian sages (be it on the basis of strict research or just instinctively) do not use letters in communicating their wisdom so as to express their doctrines and propositions in the form of imitations of voice and speech. Instead, they draw images and lay down in their temples (in the contours of those images) the intellectual content of every thing in such a way that every image forms a totality of knowledge and wisdom without being a discussion and a discursive argumentation. Afterwards the content is released from the image and put into words and the reason is found out for its being thus and not otherwise". ${ }^{2}$ Plotinus, who was himself an Egyptian and a citizen of Assiut, a town that even in those days was a stronghold of traditionalism, is writing about hieroglyphs which he seems to confuse with pictorial art and which he takes for a medium that is able to convey meaning without being bound to language and its "temporal order of syllables". This assumption made a great impression upon western minds and formed their idea about hieroglyphs and "hieroglyphic thinking", but since Champollion's decipherment of the hieroglyphic script we know it to be false: hieroglyphs render language in its temporal linearity and "mediacy" exactly like Greek and Latin and other writing systems.

In the writings of Iamblichos, another neoplatonist author in Egypt, and in the Corpus Hermeticum we meet with similar ideas about the immediately "presentifying" power of Egyptian language:

${ }^{1}$ Augustinus, Confessiones XIII,15. - An early version of this essay was presented at a conference on "institutions of interpretation" (Jerusalem, Oct. 1989). It profitted greatly from the discussion, in which Geoffrey Hartman had an important share.

${ }^{2}$ Plotin, Enneades V 8,6. 
Expressed in the original language, the discourse conveys its meaning clearly, for the very quality of the sounds and the [intonation] of the Egyptian words contain in itself the force of the things said.

Preserve this discourse untranslated, in order that such mysteries may be kept from the Greeks, and that their insolent, insipid and meretricious manner of speech may not reduce to impotence the dignity and strength [of our language] and the cogent force of the words. For all the Greeks have is empty speech, good for showing off; and the philosophy of the Greeks is just noisy talk. For our part, we use not words, but sounds full of energy. ${ }^{3}$

"Sounds full of energy", this is the linguistic equivalent to Plotinus' images. If, anywhere and at any time, "the medium was the message", it was in Egypt or rather in the minds of Egyptian philosophers and theologians of Late Antiquity who wrote Greek and retained only vague reminiscences about their native language and script. For this "Egyptian dream" that originated with the encounter of Egyptian theology and Greek philosophy, there could be found no better term than Geoffrey Hartman's "unmediated vision". ${ }^{4}$ The following essay attempts to confront this Egyptian dream with a historical reconstruction of what could be called the "classical" Egyptian way of worldreading. The liturgical recitations by which the Egyptian priests accompanied the course of the sun round the earth and which I propose to subsume under the notion "Solar Discourse" seem to me particularly revealing in this respect.

But before entering into a detailed discussion of these texts and their semantic universe, I would like so start with some statements of a more general kind regarding some ancient Egyptian concepts of the divine sphere and its relationship with the human world. This relationship, to begin with, is marked by "mediacy". According to Egyptian tradition, there was a time of immediacy when the gods did live on earth among men and were ruled, together with men, by the sun god. But men planned a revolt in consequence of which the sun god after a series of events which are not important here - finally separated himself and the gods from man by elevating the sky high above the earth and withdrawing to this new celestial abode. The government he gave over to his son, Shu, the god of the air between heaven and earth and as such the ideal mediator between what became now divided into the divine and the humane, the celestial and the terrestial sphere. ${ }^{5}$

In a way, this withdrawal of the gods to heaven and their separation from men is a reassuring concept. The gods are not to be encountered and experienced in everyday life. In this respect, Egyptian religion differs significantly from the Greek experience. The absence of the gods makes room for a specifically

\footnotetext{
${ }^{3}$ Corpus Hermeticum XVI ed. A. J. Festugière, A.D. Nock II, 230.

${ }^{4}$ Geoffrey Hartman, The Unmediated Vision: An Interpretation of Wordsworth, Hopkins, Rilke and Valéry, New Haven 1954.

5 See E. Hornung, Der ägyptische Mythos von der Himmelskuh. Eine Ätiologie des Unvollkommenen, OBO 46, 1982.
} 
human sphere of activity and responsibility: religion and its institutional frame, the state, which keeps the divine at that distance which has to be bridged by the cult. Presence gave way to representation, immediacy to mediacy. The divine absence created a kind of silence within which the liturgical voice of the solar discourse could unfold. Solar discourse is an ongoing and incessant recitation that man speaks into nature in order to create an interface, a mediating sphere, that simultaneously separates and links nature and society in the same way as the air separates and links heaven and earth. Language, by the way, and air are closely related concepts in Egyptian thought. ${ }^{6}$ Language creates a mediating space where breathing is possible. Solar discourse is the linguistic realisation of such a space that separates and links the human world and the divine world (sive natura).

According to Egyptian conviction, the world has not been created once and for all, bc-reshit, but is in a permanent cosmogonic process. In Israel, the introduction of a formal closure helps to deprive cosmos of meaning and to invest meaning into history. In Egyptian cosmology, however, there is not creation but rather an initial ignition, the moment of transition between preexistence and existence. (The Egyptian term for this moment is $z p t p j$, lit. "the first time").? This moment separates the primordial chaos (= preexistence) from the cosmogonic process, not from the accomplished cosmos. The cosmogonic process is fuelled by the conflict between positive and negative forces, creative and destructive, cosmos-making and cosmos-unmaking powers and principles. Cosmos always has to be forced on chaos, order on disorder. This ongoing chaos is different from the primordial one. The primordial chaos is transcendent, it is, in fact, the only form in which a cosmological religion or "cosmotheism" is capable of conceiving absolute transcendence; the cosmosunmaking chaos, on the other hand, is immanent, it is a kind of gravitation or entropy against which the cosmic process must constantly assert itself. From this basic conviction', many basic hermeneutical attidudes towards reality characteristic of cosmotheistic religions can be derived.

${ }^{6}$ Cf. J. Assmann, Ma'at. Gerechtigkeit und Unsterblichkeit im alten Ägypten, München 1990, 78-82.

7 On Egyptian ideas about creation and cosmogony cf. S. Sauneron, J. Yoyotte, La naissance du monde selon l'Égypte ancienne, in: La naissance du monde, Sources Orientales I, Paris 1959; J. Assmann, "Schöpfung", in: Lexikon der Ägyptologie V, 1984, 677-90; J.P. Allen, Genesis in Egypt. The Philosophy of Ancient Egyptian Creation Accounts, Yale Egyptol. Studies 2, New Haven 1988.

${ }^{8}$ I borrow this term from F.H. Jacobi, cf. H. Timm, Gott und die Freiheit, vol. I: Die Spinozarenaissance, Frankfurt 1974, $226 \mathrm{ff}$.; J. Assmann, Monotheismus und Kosmotheismus. Ägyptische Formen eines "Denkens des Einen” und ihre europäische Rezeptionsgeschichte, Sitzungsberichte der Heidelberger Akademie der Wissenschaften 1993, esp. p. 19.

${ }^{9}$ G. Balandier, Le désordre. Éloge du mouvement. Paris 1988. 
Cosmos, viewed as a process or movement, has a direction. It is moving towards order, recurrence, permanence, stability. This directionality is its meaning or 'sense' in the double significance of the english (and french) word 'sense' as 'meaning' and 'direction'. Hermeneutics in a moving world of ongoing cosmogony or creatio continua is quite different from hermeneutics in a finite and static universe. The meaning of the cosmic process is further determined by the basic conflict or opposition between order and disorder, cosmopoeic and cosmolytic forces, which convey to the process the character of a drama. ${ }^{10}$

A world threatened by chaos has to be defended, supported, maintained. This gives to the world not only meaning but interest. Man cannot remain indifferent vis à vis the cosmic drama. ${ }^{11}$ The dramatic fascination of the cosmic process engages both his imagination and his activity, it is incentive both of interpretation and of ritual. The world, as we have seen, is viewed as an openended drama. The direction $=$ sense $=$ meaning of the movement has to be discovered, articulated, enacted in order to be ensured and supported. Interpretation is participation in the drama. Order, consisting in cyclical recurrence, has to be reinforced by ritual representation. The coherence and continuity of reality depend on the uninterrupted rhythm and meticulous observance of ritual action which imposes order, recurrence and ornamental symmetry on the flux of time. Thus, the two principles of participant interpretation and ritual coherence, which are at the center of the following analysis, derive directly from the first principle of cosmotheism, namely, the world as process or drama.

10 The dramatic character of cosmotheistic world-view has often been stressed, e.g. by E. Voegelin: "The people living in the truth of the myth sensed the cosmos threatened by destruction through time; and the ritual repetitions of cosmogony purported to "annul the irreversibility of time". The experience of a cosmos existing in precarious balance on the edge of emergence from nothing and return to nothing must be acknowledged, therefore, as lying at the center of the primary experience of the cosmos" (E. Voegelin, Order and History, vol. 4, Lousisana: Baton Rouge 1974, p. 73).

${ }^{11}$ Seen from the viewpoint of modernity, this attitude appears as "animistic", compare, e.g., a statement of G. Devereux: "Man reacts with panic to the unresponsiveness of matter. His need to deny its unresponsiveness and to control his panic induces him to interpret physical recurrences animistically, and to impute to them 'meanings' which they do not possess, so as to be able to experience them as 'responses'. If stimuli interpretable as 'responses' are not forthcoming, man tends to substitute an illusory response for the (inappropriatively) expected response which is not forthcoming." (G. Devereux, From Anxiety to Method in the Behavioral Sciences, The Hague, Paris 1967, p. 32; German version: Angst und Methode in den Verhaltenswissenschaften, Frankfurt 1984, 55.)

This, of course, is not the situation of the ancient Egyptian. He reacts not to the unresponsiveness of matter - a concept totally alien to his thinking and experience - but quite on the contrary to the semantic over-stimulation to which he finds himself exposed in a world full of signification. "Matter" (as opposed to form, i.e. meaning) is a comparatively late invention. The unresponsive, panic-inspiring world of Devereux is no less man's own 
The conception of cosmos as cosmogonic drama is, as has already been pointed out, incentive both of interpretation and of representation. This explains why cosmological religion is always idolatric. The meaning inherent in the cosmic process has to be made visible. In the context of cosmotheism, representation and interpretation are acts of worship. The authors of Deuteronomy were well aware of this correlation or even identity of representation and adulation: "Do not depict them and do not adore them!". ${ }^{12}$ To make a figure of an element of the visible world is equivalent to an act of adoration. The aesthetic attitude, Kant's "disinterested contemplation of the beautiful", is categorically excluded in a cosmotheistic universe. Every act of representation is instigated by fascination and interested participation in the cosmic drama. The same applies to interpretation. Interpretation, ritual enactment and iconic representation of cosmic meaning are forms of communicative intervention in the cosmic process (with supporting or averting, adorative or apotropaic function).

$\mathrm{Vis}$ à vis a world which is both divine and constantly in the making or on the edge of collapse, man cannot remain an indifferent observer. But there seem to be two different ways of participant observation of world reading. One of them is the way of divination, in order to find out the will of the gods, the course of events in order to act and react accordingly. ${ }^{13}$ This way of world reading extracts from nature ever new texts that can be subsumed as "divinatory discourse". The other is the Egyptian way, which to me seems in many aspects the exact opposite. Here it is always one and the same text which is not extracted from but rather read into nature: the text of cultic recitation which I call "solar discourse". The decisive difference between these two ways of worldreading is to be seen in the different form of sign constitution. In divination cultures as e.g. China, Mesopotamia and Rome, signs are constituted as exceptions from the rule. The significant appears as a positive figure against the background of the regular, expectable, predictable and recurrent. In Egypt the process of semeiosis is inverse. The significant is to be found in the regular pattern. It appears as a positive figure against the background of the contingent, the deviant, the exceptional, the singular, the non-repetitive, non-recurrent event. Rain-bows, earthquakes, lunar and solar eclipses which are carefully observed and reported as

creation as was the signifying world of primitive and ancient man. Modern man's materialistic world-view induces him to imagine "man" as a being stricken with panic vis à vis a world which he until now never experienced as "matter".

${ }^{12}$ I am paraphrasing the pertinent passages in Dtn 4.16-19; 4.23; 4.25; 5.8; Ex 20,4. For a recent discussion of biblical aniconism see Chr. Dohmen, Das Bilderverbot. Seine Entstehung und seine Entwicklung im Alten Testament. Frankfurt ${ }^{2} 1987$; Chr. Dohmen, Th. Sternberg, ,... kein Bildnis machen. Kunst und Theologie im Gespräch, Würzburg 1987.

13 A. Caquot, M. Leibovici (edd.), La divination, Paris 1968. R. Guidieri (ed.); Divination et rationalité, Paris 1974. 
signs of highest importance in a divination culture are passed over in silence in Egypt as manifestations of "meaningless" disorder. ${ }^{14}$ Transeunt nubes, caelum autem manet, as Augustin has it. The point is that the Egyptian lived in a world which he believed not only to be threatened by imminent catastrophe but which he also felt himself summoned to maintain, at least to cooperate in its maintenance. Therefore, his attention was focussed on the regularities of cyclical return, renewal and regeneration. These phenomena constituted for him meaningful information that could be translated into linguistic and iconic signs. The ritual recitation of these signs in the form of solar discourse helped in his opinion to maintain the world in its continuity and connectivity by maintaining the linguistic interface, the separating and connecting space of language.

The Egyptian concept of 'Cosmos' as ongoing cosmogony is centered in the idea of the 'Solar Circuit'. ${ }^{15}$ The Solar Circuit is not just the theology or mythology of a specific god, the sun-god Re, but a process which involves the complete Egyptian pantheon, i.e. the whole world and every aspect of reality. In the concept of the Solar Circuit the Egyptian cosmotheistic idea of reality finds its most paradigmatic expression.

Central symbols of the Solar Circuit are the 2 barks, one for the night and one for the day, which serve as vehicles for the solar motion, a symbol expressive (a) of motion, (b) of the antagonistic structure of the cycle changing between two opposite phases. By means of the barks the sun-god surrounds the earth together with other deities, who play their part in the cosmic drama and accompany the sun god in changing constellations. Each phase of the process is characterized by a particular constellation. The process is thus subdivided into a number of different and meaningful events where different deities cooperate to bring about the triumph of light and motion over the opposing forces of darkness and arrest. For the main aspect of this process is its constant need of being maintained. According to the Egyptian conception the world is neither a clockwork, set into motion - once and for ever - by a divine clock-maker, nor a perpetuum mobile which goes on by itself, but a processual order which cannot persist by itself but is always endangered by the forces of disorder. The entire pantheon must cooperate in the project of maintaining the cosmic process

\footnotetext{
${ }^{14}$ I am referring here to the official and classical dogma. For exceptions, under- and countercurrents cf. my article "State and Religion", in: W.K. Simpson (ed.), Religion and Philosophy in Ancient Egypt, New Haven 1989, esp. $68 \mathrm{ff}$.

15 See J. Assmann, Liturgische Lieder an den Sonnengott, Berlin 1969 and Re und Amun. Die Krise des polytheistischen Weltbilds im Ägypten der 18.-20. Dyn., OBO 51, Fribourg 1983, esp. chapters 1-3.
} 
against the imminent threats of standstill and dissolution. The process thus acquires the features of a cosmic drama, both in the sense of 'action' and of 'suspense'. ${ }^{16}$

How is this reflected on the level of meaning? The cosmogonic character of the Solar Circuit is quite evident. The egyptian term for 'creation', $z p t p j$, "the first time" refers clearly to the idea of repetition. The Solar Circuit is nothing else then the permanent cyclical repetition of the First Moment. Texts dealing with aspects of the Solar Circuit are constantly stressing the parallelism of first time and present time, the cosmogonic moment and the ongoing process of reality. If there is a meaning, a direction in this cyclical movement, this constant reference or recourse to the first time or, in other words, the copy-originalrelationship of each time to the first time belongs to the important semantic elements. Some texts are rather explicit about the direction - and thereby the 'sense' - of the cosmic process, above all a text which deals with the 'cosmogonical moment', dating from ca. 2000 BCE:

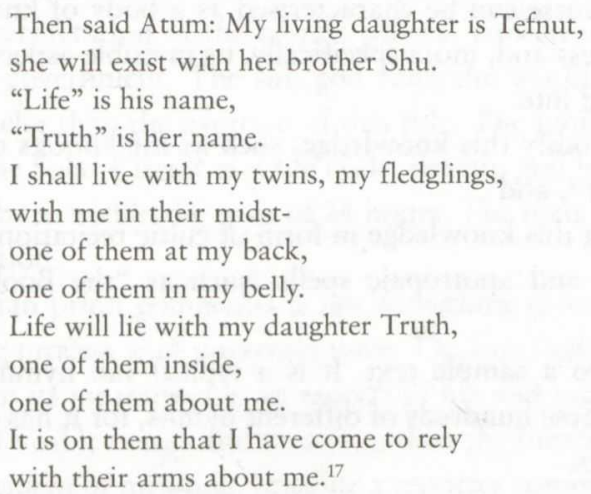

The text deals with the transition from preexistence to existence, from inertness to movement. It interprets this moment as an act of self-evolution: the preexistent unity changes into a trinity. Mythologically speaking, this is the engendering of Shu, the god of air, and Tefnut, the goddess of moisture, by Atum, the primeval and creator god. But this text gives an interpretation of the ancient myth which anticipates the procedures of allegoresis by almost 2000 years. It interprets Shu as "life" and Tefnut as "truth"/“justice"/“order". Life and Truth appear in this text as the cosmogonic principles par excellence, which determine the direction, the 'sense' of the first movement and by necessity determine the sense of existence as well. The name of Atum needs no interpretation because it has a clear meaning: the "whole" which at the same time means

${ }^{16}$ For the Egyptian "theology of maintenance" and the role of the king (the state) in this task cf. my "State and Religion".

${ }_{17}$ CT II 32b-33a cf. J.P. Allen, Genesis in Egypt, 22; 25-27. 
"the nonexistent", thus referring to the idea of a transcendent primordial and preexistent unity/totality.

According to this text the cosmic process is moving in the direction of "Life" and "Truth". This interpretation can be confirmed by a semantical analysis of the Solar Discourse, where the notions of life and truth recur over and over again.

The maintenance of the cosmic process is one of the tasks devolving on Pharaoh and which is delegated by him to the sacerdotal institutions of the solar cult. The main function of the solar cult is the maintenance of the cosmic process by incessant recitation. The solar cult is therefore productive of texts in a most singular way. A whole body of literature which, in its original extent, might well equate the extent of the bible and which still fills several volumes in modern translations, has the solar cult as its "Sitz im Leben", the interpretation of the cosmic process as its subject and the maintenance of this process as its function. It is this literature which I will be referring to as the 'Solar Discourse'. The Solar Discourse can be characterised as a body of knowledge concerning the cosmic process and, more specifically, its invisible aspect as a divine drama. It can be divided into

- texts which codify this knowledge, such as the "books of the netherworld" (cosmographies) $^{18}$, and

- texts applying this knowledge in form of cultic recitation like

hymns, litanies and apotropaic spells (such as "the Book of Overthrowing Apep").

Let us turn to a sample text. It is a typical sun hymn, perhaps the most classical of all these hundreds of different hymns, for it has come down to us in some 50 variants.

Hail to you, Re, at your rising

Atum, at your beautiful setting

You appear and shine on the back of your mother appearing as King of the Ennead

Nut greets you with $n j n j$

Maat embraces you at all times

You cross the sky with expanded heart

The Lake of Two Knives is now at peace

The enemy is fallen, his arms bound

The knife has cut through his spine

$\mathrm{Re}$ is in a fair wind

The Msktt boat has destroyed its attacker

The southerners and northeners tow you

${ }_{18}$ For an anthology of these texts in German translation see E. Hornung, Ägyptische Unterweltsbücher, Zürich and Munich ${ }^{2} 1984$. 
These sun hymns could be characterised as 'describing' the Solar Circuit. They accompany the cosmic process with its description. But the description concentrates on what is invisible, on the hidden meaning of the visible phenomena. Thus, the speech-act could be more properly classified as 'commenting', rather than 'describing'. The priest gives not a description but an interpretation of what is going on in the sky. My thesis is that the Solar Discourse in its different genres is au fond nothing else than a kind of interpretation, applied to the Solar Circuit.

The meaning of the cosmic process, as it is displayed in this body of interpretive literature, is centered around two different points of focus: a political one and a biological one; or, to use the terminology of Hans Kelsen and Ernst Topitsch ${ }^{20}$, there are two levels of interpretation: a sociomorphic level and a biomorphic one. We easily recognize in these two levels the two cosmogonic principles of the text quoted above, Life and Truth/Justice/Order.

The political interpretation of the cosmic process conceives of maintenance as the exertion of government. The sun god rules the world, and the cosmic process is nothing else than the exertion of this rule. The biological interpretation conceives of the Solar Circuit as a life cycle, the sun god being born, aging, dying and being reborn within the span of 24 hours. The texts combine the two levels of interpretation.

What the Egyptian priest comments is not something given and final like a text but an ongoing process with uncertain issue. The function of the interpretation is to strengthen its meaning, i.e. its aspects of life and order. If 'cosmos' is the combination of visible events and meaning, then the function of this recitation is the reinforcement of meaning. Imagine a reporter commenting a game of soccer and determining by the power of his commentary the course and issue of the match, and you get an idea of the function of recitation in the Egyptian Solar cult. This is what I propose to call 'participant interpretation'.

The hermeneutical methodology implied in this cultic exegesis of the cosmic process can be characterized by the following traits:

1. Simultaneity of 'text' and 'commentary'.

'Text' and 'commentary' are simultaneous. The commentary gives an accompanying disambiguation of the text as it unfolds, by constantly referring to the main semantical points of focus: [LIFE] and [GOVERNANCE]. Interpretation, in

19 Translation: H.M. Stewart, "Traditional Sun Hymns of the New Kingdom", Bull. Inst. of Archaeology VI, 1967, 49; cf. my Liturgische Lieder, 263-79.

${ }^{20} \mathrm{H}$. Kelsen, Society and Nature. A sociological Inquiry, Chicago 1943; E. Topitsch, Erkenntnis und Illusion. Grundstrukturen unserer Weltauffassung, Hamburg 1979. 
this case, means simultaneous and continuous disambiguation of the ongoing text.

2. Inexhaustibility.

There is no end of possible interpretations. And there are no contradictions between different interpretations. Images which according to our logic seem mutually exclusive appear peacefully side by side in one and the same text, even sentence. This principle has for the first time been ascertained by H. Frankfort, who characterized it as a "multiplicity of approaches", leading to a "multiplicity of answers". ${ }^{21}$ The sunrise is interpreted, e.g., both as spontaneous emergence $(b p r)$ - repeating the emergence of Being in the First Time, the cosmogonic moment, - and as birth or rebirth ( $m s w t)$ of the sun-god by the mother-goddess Nut or "Heaven". The sun-god rises from the primeval ocean, he comes forth from the vulva of his mother and he changes barks, passing from the bark of the night, Mesektet, on to the bark of the day, Me'andjet. The sky may be represented as a woman, or a cow, or a watery expanse, the motion of the sun may be called 'sailing' in a boat, or 'flying' over the sky, or 'running' etc. There is an inexhaustible profusion of interpretive images, reminiscent of R. Akiba's mountains of halakhot, extracted out of a single yota of the Torah.22 All these different interpretive phrases and images may point towards Life and Order as the holy sense of the process.

3. Interpretation, not explanation.

The reason why the images do not contradict each other is because they are not meant as explanations, but as interpretations. Interpretation is concerned with meaning. This is an endless quest. Explanation asks for laws and causes and only one of differing explanations can be held true at a time. A case in point is the Egyptian theory about the sources of the Nile and the causes of the inundation. ${ }^{23}$ An explanatory approach to these phenomena would follow the course of the river up into Ethiopia and Central Africa, would finally discover its sources and also the reason for the annual inundation. For the ancient Egyptians this explanation would be destitute of meaning. They were not interested in African rivers, but in the Egyptian Nile. This, of course, has to be divided into an Upper Egyptian Nile and a Lower Egyptian one, because Egypt is the union of two constituent countries. Accordingly there must be two sources of the Nile which are to be located at the point were the river enters the respective country, one at Assuan and the other south of Cairo. Moreover, there is no reason why the Nile should not simultaneously exist in 42 fold shape, one Nile for every nome, each provided with his own source. The Nile comes to Upper and

\footnotetext{
${ }^{21}$ H. Frankfort, Ancient Egyptian Religion, New York 1948, pp. 3-29.

22 Bab. Talmud Menahot 29b.

${ }_{23}$ Cf. B.H. Stricker, De overstroming van de Nijl, Mededelingen en verhandelingen van het vooraziatisch-egyptisch genottschap "Ex Oriente Lux" No. 11, Leiden 1956.
} 
Lower Egypt not from the south but from the Netherworld, from the Beyond. Every element of the biocosmical sphere is a visible manifestation of the invisible divine drama. Interpretation aims at naming these actions, constellations, events in the invisible reality, the interconnection of which makes up the visible world.

\section{Disambiguation by Polarization}

Interpretation operates by binary polarization: life and death, order and disorder are distinctions which bestow meaning onto the flux of appearences and make the world unambiguous. Explanation is quite indifferent regarding these distinctions. For this reason it is without interest for the Egyptian mind. The Egyptian wants to identify a phenomenon as belonging to the domain of life and order or to that of death and disorder, in order to decide whether to support it or to avert it. For him the world is a matter of distinction and decision: he must decide how to interpret in order to know how to act. The world thus assumes a highly anthropomorphic and moral meaning. The cosmogonic forces are fighting the case of life and order, and man participates in this combat because his life and order depend on its issue.

5. Mutual Modeling or Analogical Imagination.

But the interpretive projection of the human into the cosmic functions both ways: the anthropomorphosis of Cosmos is met by the cosmomorphosis of Man. In interpreting the phenomenology of the Solar Circuit in terms of life and death, order and disorder, he interprets and organizes his conceptions about life and death and about the socio-political forms of order and disorder (rebellion, war) in terms of cosmical phenomenology. The cosmic process is modeled in terms of life and governance, and the concepts of political, social and individual welfare are modeled in terms of solar language.

6. Iconicity and narrativity.

In the course of the last paragraphs, we have constantly referred to the basic units of interpretation as 'images'. There is always a certain indecision whether to conceive of these units as belonging to the order of language or rather to the order of iconic representation. The easiest way to resolve this dilemma is to distinguish between a deep and a surface structure. In the deep structure the articulations of meaning are general enough to allow for both an iconic or a verbal realization on the surface structure. Elements belonging exclusively to the sequentiality of language as, e.g., the narrative "functions" in the sense of V. Propp clearly belong to the surface structure. This means that the 'text' of the cosmic process, to which the interpretive discourse refers, is not organized in terms of narrative coherence. I propose to call the deep structure units of the interpretive discourse "icons" in the sense of Hans Blumenberg ${ }^{24}$, icons which

\footnotetext{
${ }^{24}$ Cf. H. Blumenberg, Arbeit am Mythos, Frankfurt 1979.
} 
may be transformed by means of surface realization into pictorial representations or mythical narratives.

\section{Depth}

There are different levels of interpretation. Interpretations can be rather 'flat', like e.g. interpreting the motion of the sun as sailing in a boat, and they can be rather deep. The interpretation of Shu and Tefnut as Life and Truth I would classify as comparatively deep. A classical example of 'deep' interpretation seems to me the idea of a union of the Sun-god Re and Osiris, the god of the dead, during midnight. ${ }^{25}$. In this union, we are told, the two aspects of time unite, $N b \underline{h}$, eternal repetition, and $\underline{d t}$, eternal duration, and by their union they bring about time as such, as continuity. The same event is interpreted also as an encounter of father and son in the netherworld, united in a mutual embrace. The father represents the past, yesterday, the son the future, the morrow.

\section{Participation and identification}

To know the meaning of the cosmic process, i.e. the divine "icons" unfolding and articulating this meaning calls for (and makes possible) participation in, and even identification with, the divine. This is stated over and over again in those texts of the Solar Discourse, which we have classified as "codifications" of this knowledge. ${ }^{26}$

These sorceries of Isis and the Eldest Sorcerer for repelling Apopis from Re in the West are performed in the hidden part of the netherworld. They are performed upon earth as well. The one who performs them is one who is in the bark of Re in the sky and in the earth. (It is only) the select who can know this design without the knowledge of which the Fierced Faced One (i.e. Apopis) may not be repelled. ${ }^{27}$

The one who knows these secret designs is an outfitted Akh. He goes out and comes in within the netherworld. ${ }^{28}$

The one who knows this images becomes the likeness of the great god himself. ${ }^{29}$

The sun priest while performing the adoration of the sun god becomes one of the baboons, the mythical entourage of the sun god:

I chanted hymns to the sun god,

I joined the solar apes,

I am one of them.

I have acted as second to Isis,

I have strengthened her powers,

I have knotted the rope

25 See my Liturgische Lieder, 101-105.

${ }^{26}$ A collection of these statements gives E.F. Wente, “Mysticism in Pharaonic Egypt?", in: JNES 41, 1982, pp. 161-179.

27 Amduat ed. E. Hornung, Das Amduat. Die Schrift des Verborgenen Raumes, 3 vols., Äg. Abh. 10 and 13, Wiesbaden 1963/67, vol. I, p. 123, lines 2-5, transl. Wente.

28 Amduat, Short Version ed. Hornung, Amduat, vol. III, verses 297-99.

29 ibd., verse 14. 
I have driven off Apep,

I have put a stop to his movements,

Re has given his hands to me

and his crew will not drive me away. ${ }^{30}$

\section{III}

The Egyptian term for the Solar Discourse in its applied form of cultic recitation is "Causing Maat to ascend (to the bark of the sun-god)". Maat ("truth, justice, order") is believed to emanate from the sun god through his radiation and motion and to fill the world with order and meaning. By the cultic recitation this emanated Maat is restituted to the sun god.

The speech of the priest is "truth" itself, because it refers not just to the cosmic process, e.g. sunrise, but to the cosmic process in its aspect of success and recurrence, i.e. in its aspect of signification. We mentioned that the Egyptian way of sign constitution takes the recurrent pattern for a manifestation of order and as such for significant whereas the exceptional and deviant passes as insignificant and a manifestation of disorder. The truth of the cosmic 'text' lies in its repetitive and cyclical phenomena like sunrise and sunset, viewed under the auspices of success and triumph.

In the sun hymns, the sun god is told the truth about sunrise or sunset and is thus assisted during the crisis which is implied in every transitional phase between cycles like day and night. The sun god is distinguished among the gods as the one who lives on Maat, whose sacrificial nourishment consists in Maat. With regard to the sun god, the recitation of Maat is therefore the life-giving act par excellence. By interpreting the cosmic process, by ritually proclaiming the truth of it, the priest vivifies the sun god and thus contributes to the maintenance of the world.

We are dealing here with a circular structure underlying the Egyptian idea of sacrifice and of communication in general. In the present context we can only very briefly allude to these concepts nor can we completely avoid mentioning them because interpretation here functions as a form of communication and even of sacrifice. The Egyptians associated the practice of offering with the meaning of restitution, of restoring to a deity a symbolic specimen of precisely that part of reality which he/she is believed to dominate or to generate. Thus a deity is given back what he/she herself gave. To give, in terms of sacrifice, means to give back. We are dealing here with the social or communicative function of giving which has been analyzed by Marcel Mauss in a classical

\footnotetext{
${ }^{30}$ Book of the Dead, ch. 100, see R. O. Faulkner (transl.), The ancient Egyptian Book of the Dead, London 1985, 98.
} 
study. The social function of giving consists in keeping things circulating. ${ }^{31}$ The circulation of things functions as a means of establishing and assuring social identity and cohesion. The institution of sacrifice, in Egypt, is an extension of this idea of communicative circulation onto the divine world. The divine, i.e. the cosmic, is thereby integrated into the realm of social identity and coherence. The sun god as the protagonist of the Solar Circuit is given Maat as a sacrifice: the author of the cosmic text is presented with its interpretation, in order to assure its meaning, i.e. its directional sense towards Life and Truth, and to assure an identity and coherence which encompasses the human and the cosmic spheres.

The active and supporting force which the sun priest exerts over the cosmic process by reciting his hymn is referred to as "the $3 b$-power which is on his mouth", e.g.

Helper of the sun god, who overthrows his enemies
by the $b$-power on his mouth,
who causes the sun bark to sail in joy. ${ }^{32}$

There is a whole theory of performative recitation implicit in the Egyptian notion ' $h$, which is crucial for our analysis of Egyptian hermeneutics.

The root ${ }^{3} b$ has a complex meaning ${ }^{33}$ which can be circumscribed in English by the three notions of

- 1. light (radiance, brilliance, luminosity)

- 2. power (magical, spiritual), spirituality

- 3. efficiency (beneficiality, utility)

Nominal derivates are:

$(j)^{2} b$ "sunbeam"

" $b$ "luminous spirit", a state into which the dead are transformed or "transfigured" by the funerary rites.

"h "horizon", lit. the "luminous place" where the sun sets and rises, also a sort of celestial paradise where the deceased hope to make their abode. ${ }^{34}$ "by w "magical power" (particularly of speech)

$s^{3} b w$ "transfiguration", a genre of recitations which serve to transfigure the

31 There is an Egyptian text which gives a surprisingly abstract and explicit definition of this principle: "act for him who has acted in order to keep him acting" (Bauer B1, 109-10.) cf. J. Assmann, Ma'at. Gerechtigkeit und Unsterblichkeit im Alten Agypten, Munich 1990, 60-69, 190-195.

${ }^{32}$ The Epigraphic Survey of Egypt, Medinet Habu VI, pl. 422-3.

${ }^{33}$ See G. Englund, Akh - une notion religieuse dans l'Égypte pharaonique Uppsala 1978; Fl. Friedman, "The Root Meaning of X: Effectiveness or Luminosity", in: Serapis 8, 1984/85, 39-46, and esp. R.K. Ritner, The Mechanics of Ancient Egyptian Magical Practice, Studies in Ancient Oriental Civilization 54, Chicago 1993, 30-47.

${ }^{34}$ See J.P. Allen, "The Cosmology of the Pyramid Texts", in: W.K. Simpson (Hg.), Religion and Philosophy in Ancient Egypt, YES 3, New Haven 1989, 1-28, esp. 19-26. 
deceased into an $b$, a luminous spirit, thus exerting a power of speech which is not only performative but transformative.

Common to all these applications of and derivations form the root ${ }^{2} b$ is the idea of 'Beyond'. ' $b$ is the Egyptian notion which comes closest to the idea of transcendence or the holy. The holy is a state which is luminous, spiritual, powerful and efficient. It is also "celestial". In the context of cosmotheism, the celestial is a form of intra-mundane transcendence, the notion of the transmundane being categorically excluded. The notion of $b$ refers to a region behind the borderline separating this world from that world, where the sun sets and rises, where the dead go after burial, where the light comes from and where the magical speech may reach under the appropriate circumstances. $b$ is a bifocal term: it denotes an element of yonder world, a signified, and an element of this world which serves as its signifier, exactly in the same way as our notion of "holy" or "sacred" refers as well to a thatworldly condition as to thisworldly entities like texts, symbols, persons, places, times etc. which hold a relationship with the transcendent. ${ }^{35}$ If a word, an object, an action reaches to the beyond and achieves not only to represent, but magically to "presentify" 36 , to bestow thisworldly presence to an entity of yonder world, it acquires a kind of aura, a luminous power and efficiency.

Where luminosity and holiness are thus intimately related, the sun becomes the very paradigm of holiness. In the context of cosmotheism, holiness is a cosmic phenomenon, and the beyond is to be located within the cosmos. But notwithstanding the intramundane character of the holy and the beyond, the borderline between this world and that world must not be blurred. The Egyptian notion of "that world" is determined by the concept of the Solar Circuit: it is the region which is pervaded and dominated by the sun-god during his cyclical movement. The Egyptian notion of holiness, thatwordliness, transcendence in a sense, implies the idea not of categorical alterity and absolute transcendence, but of remoteness and difference. The magical or sacramental act has the power to bridge this distance and to give presence to the holy. Language, and symbols in general, have the power to make the distant present. They "stand for" something they represent, not the thing itself, but its meaning. The word "cake" can be uttered even in a context where no real cake is at hand. It cannot replace a real cake but it can evoke its mental image, its "meaning", even where nothing in the real situation suggests such a thing. With regard to the holy, the distant par excellence, this capacity of symbolic presentification becomes dramatically important. As the holy is pure meaning, its symbolization

35 There are even languages which distinguish between the absolute and the relational holiness, e.g. hagios and hosios in Greek, and sacer and sanctus in Latin, see A. Dihle, "Heilig", in: Reallexikon für Antike und Christentum, s.v.

${ }^{36}$ Cf. J.P. Vernant, "De la presentification de l'invisible a l'imitation de l'apparence", in: Image et Signification, Rencontres de l'Ecole du Louvre (1983) $25 \mathrm{ff} ., 293 \mathrm{ff}$. 
is not vicarious. The symbolized holy and the holy symbol interfuse. The sacred text, when recited, thus turns into a manifestation of the holy, a sort of verbal sanctuary, where the holy acquires thisworldly presence. This is what the expression 'bw tpjw $r$, "the "b-power on the mouth" means. It refers to the recitation of "sacred texts", a recitation which has the power of re-presenting, enacting the most distant meaning of all: the holy.

Where representation turns into presentification, however, language becomes opaque; its communicative function is superseded by its magical "energy" which has nothing to do with meaning, because it is lost in translation. The theory behind this practice can be found in Graeco-Egyptian texts of Late Antiquity, e.g. in the opening chapters of treatise XVI from the Corpus Hermeticum, from which we quoted at the beginning of this essay. ${ }^{37}$

The energetic theory of language is magical. The magical force of spells resides in their sound. It is the sound, the sensual quality of speech, which has the power to reach the divine sphere. The sacred word - $b w$ tpjw $r^{3}$-denotes the holy and makes it present. But the holy, with regard to the Solar Circuit, is not something static, but a cosmogonic energy active in the cosmic process. The word which denotes and presentifies the sacred meaning of the cosmic process releases the cosmogonic energies themselves. The general principle implied in this type of speech act is very common in archaic societies. Cosmogonic myths are recited in periods of crisis, liminal phases of transition from one cycle, one phase to another, as well as in cases of sickness or danger in the domestic sphere. A famous case is the recital of the Enuma Elish, the babylonian Creation Epic, during the New Years Festival (akitu), but cosmogonic myths serve also as medical incantations. ${ }^{38}$ In Egypt, similar recitations and incantations regularly refer to the Solar Circuit as the permanent cosmogony. In the context of the solar cult they are meant to assist the sun god and to strengthen the cosmogonic energies in combatting the forces of evil and the drift towards chaos; in magical contexts, however, they raise the cosmogonic forces against all kinds of mishap, which are such "interpreted" as manifestations of disorder. Performative interpretation thus can be defined as a kind of interpretation which not only refers to the meaning of a text, but releases and thereby realizes this meaning. It is particularly effective in dealing with ambiguous texts like the Solar Circuit, the meaning of which (its directional sense) is always struggling against meaninglessness, entropy, disorder, chaos. Performative interpretation brings about what it denotes, it makes meaning shine forth in the course of the cosmic drama.

37 Corpus Hermeticum XVI ed. A. J. Festugière, A.D. Nock II, 230; transl. G. Fowden, The Egyptian Hermes. A historical approach to the late pagan mind, Cambridge 1986, 37.

${ }^{38}$ M. Eliade, "Kosmogonische Mythen und Magische Heilungen", in: Paideuma 6, 1954/58, 194-204. 
Perhaps it is not mere coincidence that the first to systematically stress the "pragmatic" function of language was a very prominent egyptologist, A.H. Gardine $^{39}$. In those years Gardiner happened to be in contact with linguists and anthropologists of the functional school like R. Firth and B. Malinowski. It seems to me easily imaginable that an egyptologist like Gardiner who had devoted decades of careful study to Egyptian sacred and magical texts could be led quite naturally to the conception of a performative theory of language, of words which not just denote what they mean but literally realize, enact, bring about their meaning in the performance of their pronunciation. For the Egyptians not only made ample use of this function of language but even formed conceptions about it. One of them is the concept of ${ }^{~} \mathrm{bw}$, spiritual power, which applies to sacred and magical functions in the religious sphere, another is $b w$, authoritative power, which applies to royal orders in the political sphere. Both the words of the priest/magician and those of the ruler possess the power of immediate realization. The concept of " $h$ thus relates to the Solar Discourse not only the notion of "bridging" or "mediating", of words reaching into the spiritual sphere of divine actions and constellations, but also the notion of "enacting", the power to realize what the words denote.

${ }^{39}$ A.H. Gardiner, The Theory of Speech and Language, Oxford 1932. Gardiner himself points to Philipp Wegener and his Untersuchungen über die Grundfragen des Sprachlebens, Halle 1885, as his predecessor. The discovery of the sensu stricto "performative" function of speech is due to J.L. Austin, How to do things with words, Oxford 1962. 